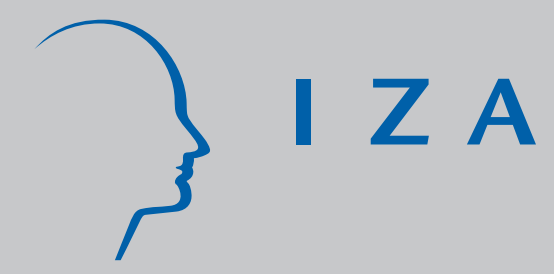

IZA DP No. 336

\title{
Careers and Wage Growth within Large Firms
}

\author{
Francisco Lima \\ Pedro Telhado Pereira
}

J uly 2001 


\title{
Careers and Wage Growth within Large Firms
}

\author{
Francisco Lima \\ Universidade Lusófona de Humanidades e Tecnologias \\ Pedro Telhado Pereira \\ Universidade Nova de Lisboa, CEPR and IZA, Bonn
}

Discussion Paper No. 336
July 2001

\author{
IZA \\ P.O. Box 7240 \\ D-53072 Bonn \\ Germany \\ Tel.: +49-228-3894-0 \\ Fax: +49-228-3894-210 \\ Email: iza@iza.org
}

This paper can be downloaded without charge at:

http://papers.ssrn.com/abstract=xxxxxx

An index to IZA Discussion Papers is located at:

http://www.iza.org/publications/dps/

This Discussion Paper is issued within the framework of IZA's research area The Future of Work. Any opinions expressed here are those of the author(s) and not those of the institute. Research disseminated by IZA may include views on policy, but the institute itself takes no institutional policy positions.

The Institute for the Study of Labor (IZA) in Bonn is a local and virtual international research center and a place of communication between science, politics and business. IZA is an independent, nonprofit limited liability company (Gesellschaft mit beschränkter Haftung) supported by the Deutsche Post AG. The center is associated with the University of Bonn and offers a stimulating research environment through its research networks, research support, and visitors and doctoral programs. IZA engages in (i) original and internationally competitive research in all fields of labor economics, (ii) development of policy concepts, and (iii) dissemination of research results and concepts to the interested public. The current research program deals with (1) mobility and flexibility of labor markets, (2) internationalization of labor markets and European integration, (3) the welfare state and labor markets, (4) labor markets in transition, (5) the future of work, (6) project evaluation and (7) general labor economics.

IZA Discussion Papers often represent preliminary work and are circulated to encourage discussion. Citation of such a paper should account for its provisional character. 
IZA Discussion Paper No. 336

July 2001

\section{ABSTRACT}

\section{Careers and Wage Growth within Large Firms*}

The relationship between the worker's career path and wage growth is studied using a longitudinal sample of large firms. The econometric analysis shows that promoted workers receive a positive wage premium even if they stay in the same job level. Demotions are associated with negative wage premiums. The wage-career dynamics generates a U-shape to the wage premiums for promotions over the hierarchical ladder. In the context of the model discussed, this shape suggests a stronger learning and/or human capital accumulation effect at the bottom of the hierarchy and a stronger job assignment effect at the top.

JEL Codes: J32, J33, M12

Keywords: Careers, promotions, wage growth

Pedro Telhado Pereira

Faculdade de Economia

Universidade Nova de Lisboa

Travessa Estevão Pinto

P1099-032 Lisboa

Portugal

Tel.: 351213801600

Fax: 351213871105

Email: ppereira@fe.unl.pt

\footnotetext{
* Financial support from PRAXIS XXI, grant 2/2.1/CSH/781/95 and SAPIENS99 - 33089 is acknowledged. Francisco Lima also acknowledges the support from PRAXIS XXI - Subprograma Ciência e Tecnologia do $2^{\circ}$ Quadro Comunitário de Apoio. We also thank the Bank of Portugal, where this research was carried out.
} 


\section{Introduction}

The relationship between employers and employees is rather complex and subject to different dimensions of analysis. One such dimension is the wage growth associated with the employee's career progression inside the firm. The real world is replete with examples of job ladders that individuals climb during their working lives and of the major pay changes that accompany those steps. Who among us has never longed for new responsibilities, a new position, a prize?

The objective of this paper is to determine how the individual wage growth is effected by different career events. The main questions are the following. What is the effect of promotion on the wage growth? How does the wage growth depend on the hierarchical position held by the employee? To what extent are human capital accumulation and learning about individual abilities reflected in wage paths? What is the effect of demotions? Past empirical work has dealt with these issues, but the relationship between the workers' career path and the associated wage path has been left mostly uncovered. Moreover, it is still rare to find studies using a panel of personnel records from multiple firms. The present work uses such data, a longitudinal matching employer-employee sample of large firms. The sample is unique in the sense that it covers the entire work force of multiple firms, as opposed to single-firm-based studies or individual-based studies. A theoretical model that takes into account several aspects of the workers' progression within firms is presented to guide the econometric analysis performed. 
What are the results that can be found in the literature? ${ }^{1}$ The papers of Baker, Gibbs, and Holmstrom $(1994 a, b)$ present one of the more comprehensive studies on the subject. These authors analyze twenty years of personnel data from one firm, focusing on the hierarchy, promotion policies, port of entry and exit, pay policies and their relationship with the hierarchical levels. The authors found an average positive wage premium for promotion, ranging from $5 \%$ in the lowest job level to $22 \%$ and $15 \%$ in the highest ones; small or negative average wage premium for demotion or staying in the same job level. Promotion is defined as moving to upper job levels. More recently, Lazear (1999) explores some new directions with the analysis of personnel records of two different firms. An overall promotion effect implies a 13$14 \%$ estimated annual wage increase. Seltzer and Merrett (2000) also found that wages increase upon promotion using personnel records from a Bank covering six decades, an unusually long period.

The above results are for single-firm studies. There are other studies that use data on a sample of individuals. For example, McCue (1996) presents evidence on the positive and important effect that workers' movements inside the firm have on wage growth using the Panel Study of Income Dynamics. The individual's reported job change is used to define promotion. The wage decomposition performed shows a 9$18 \%$ effect over the life cycle due to promotion or other reassignment. Pergamit and Veum (1999) study the causes and consequences of promotions using the National Survey of Youth. Several promotion types are identified, such as position upgrade or

\footnotetext{
${ }^{1}$ Surveys of the literature can be found in Gibbons and Waldman (1999b), Prendergast (1999), and Gibbons (1997).

${ }^{2}$ The estimated effect is somewhat less than the one found in the previous study, near $1 \%$, though, using their data (Table 6, p.599), one can infer that the wage premium ranges from $8 \%$ in the lowest rank (Clerk) to $16 \%$ in the highest rank (Inspector).
} 
lateral move. The estimated effects on the annual wage growth range from zero to $12 \%$.

The data set used in this study is a panel of large firms and it includes personnel information regarding all of the workers employed therein, namely, the workers' job transitions within firms and the associated promotion/no-promotion event. Not only can the movements to upper hierarchical layers be identified - commonly defined as promotions - but whether or not these movements are associated with a promotion, as defined by the employer in the survey, as well. Therefore, the workers' promotions with no change in the hierarchical position are also observed. The detailed information concerning the workers' career progression allows us to test several theoretical results and to depart further from previous applied research.

This paper is organized as follows. The next section presents a model that combines job assignment, human capital investments, and learning. It is based on the Gibbons and Waldman (1999a) model in order to explore certain aspects of the firms' wage policies determined by the employees' career progression, namely, how the relative importance of job assignment, human capital investments, and learning interact to shape the size of the wage growth along the hierarchical ladder. The data set is presented in the third section. The applied analysis is performed in Section four. The career effects on the wage premiums are studied in detail. The econometric results show that promoted workers receive a positive wage premium even if they stay in the same job level, but there are almost no wage premiums for the unpromoted workers who also stay in the same job level. Demotions are associated with negative wage premiums. The wage-career dynamics generates a U-shape to the wage

\footnotetext{
${ }^{3}$ Baker, Gibbs, and Holmstrom (1994a) is probably the only study that tries to disentangle the relationship between the workers' career path and wage growth, using detailed information on the workers' hierarchical position.
} 
premiums for promotions over the hierarchical ladder. The paper ends with some concluding remarks.

\section{The Model and Empirical Specification}

\section{The Model}

The model used to study the worker's wage growth and career path is based on the Gibbons and Waldman (1999a) integrative model. A hierarchy with an arbitrary fixed number of ranks is introduced to capture the different possible shapes of workers' compensation in a better way. The model combines job assignment, human capital investments, and learning about the employees' abilities. This combination has the advantage of producing a set of results, which are in line with the available evidence on firms' personnel policies.

Consider a firm that uses only labor as input and where each worker $i$ is assigned to a job level $j=1, \ldots, J$ and produces $y_{i j t}$ in period $t$ given by

$$
y_{i j t}=d_{j}+c_{j}\left(\eta_{i t}+\varepsilon_{i j t}\right)
$$

\footnotetext{
${ }^{4}$ There are other models where job assignment and career progression are contemplated. The examples are abundant, to name a few: matching (Jovanovic 1979); comparative advantage (Sattinger 1975); scale-of-operations effect (Waldman 1984a); up-or-out contracts (Kahn and Huberman 1988 and Waldman 1990); tournaments (Lazear and Rosen 1981); asymmetric information and signaling (Waldman 1984b, Ricart I Costa 1988, Bernhardt and Scoones 1993 and Bernhardt 1995); asymmetric information and visibility in the labor market (Milgrom and Oster 1987).
} 
where $d_{j}$ and $c_{j}$ are technological coefficients, with $0<d_{J}<d_{J-1}<\ldots<d_{1}$ and $c_{J}>c_{J-1}>\ldots>c_{1}>0$; the term $\varepsilon_{i j t}$ is a normal error term with mean 0 and variance $\sigma^{2}$; and $\eta_{i t}$ is the worker effective ability. This effective ability $\eta_{i t}$ is a function of the worker's innate ability $\theta_{i}$ and labor market experience $x_{i t}$,

$$
\eta_{i t}=\theta_{i} f\left(x_{i t}\right)
$$

with $f_{x}>0$ and $f_{x x}<0$. The worker can have high $\left(\theta_{H}\right)$ or low $\left(\theta_{L}\right)$ innate ability, with $\theta_{H}>\theta_{L}>0$. Assume also that there is free entry in production, firms are all equal, and workers supply one unit of labor in each period $t$.

Consider an economy where there is incomplete information about workers' ability: as the worker advances in his career, the firms learn about his ability. Assume that this learning is symmetric: all firms and the worker hold the same amount of information in any period $t$. In this case, $\eta_{i t}^{e}=\theta_{i t}^{e} f\left(x_{i t}\right)$, where $\eta_{i t}^{e}$ and $\theta_{i t}^{e}$ represent, respectively, the worker $i$ 's expected effective and innate ability in period $t$. The worker $i$ 's expected innate ability is a function of his performance realizations, that is, $\theta_{i t}^{e}=E\left(\theta_{i} \mid \eta_{i t-x}+\varepsilon_{i j t-x}, \ldots, \eta_{i t-1}+\varepsilon_{i j t-1}\right) !$

The main proposition states that worker $i$ is efficiently assigned to job 1 if $\eta_{i t}^{e}<\eta^{1}$, to job $2 \leq j \leq J-1$ if $\eta^{j-1} \leq \eta_{i t}^{e}<\eta^{j}$, and to job $J$ if $\eta_{i t}^{e} \geq \eta^{J-1}$. Given competition, wages are given by

\footnotetext{
${ }^{5}$ The worker's performance in period $t-1$ is nothing more than the signal sent to the market by the realization of output in $t-1$. Moreover, the signal is independent of job assignment because $\eta_{i t}+\varepsilon_{i j t}=\left(y_{i j t}-d_{j}\right) / c_{j}$ from equation (1).
} 


$$
w_{i t}=d_{j}+c_{j} \eta_{i t}^{e}
$$

with $j=1, \ldots, J$. The other results derived from the model are that promotion implies a wage increase; it is possible to observe wage decreases; demotions, although rare, imply a wage decrease; wages are serially correlated; wage increases predict promotion. The full model is exposed in Gibbons and Waldman (1999a). In the original framework $J=3$ and the extension to an arbitrary $J$ does not change the main results of the original model. The necessity to have more than three job levels will become clearer when discussing the wage growth upon promotion in the following.

The objective of assessing the impact of workers' careers on wage growth, and namely, to determine the wage premium associated with promotions along the hierarchical ladder, means that the expressions suitable to the analysis are given by first-difference wage equations. Two cases are possible. First, the worker can stay in the same job level $j$ in two consecutive years and his wage growth is (omitting the subscript $i$,

$$
w_{t+1}-w_{t}=c_{j}\left[\theta_{t+1}^{e} f(x+1)-\theta_{t}^{e} f(x)\right]
$$

or, the worker is promoted from job level $j$ to job level $j+1$ and his wage growth is

$$
w_{t+1}-w_{t}=\left(d_{j+1}-d_{j}\right)+c_{j+1} \theta_{t+1}^{e} f(x+1)-c_{j} \theta_{t}^{e} f(x)
$$

What is the relative size of the wage growth along the worker's career path? It will depend on the relative magnitude of the job assignment, human capital accumulation and learning effects. The human capital accumulation effect is related with the change 
in the human capital function $f($.$) induced by the increase in x$. The human capital effect is always decreasing in the job level due to the concavity assumption. If the human capital accumulation effect is very strong in the beginning of the worker's career - function $f($.$) highly concave - then the wage increase will be relatively high$ at the bottom job levels. If the effect of human capital accumulation is fairly constant along the worker's career - function $f($.$) close to linear - then the wage growth due to$ this effect will be fairly equal along the job ladder.

The job assignment effect is related with the slope $c_{j}$ of the worker's production when the worker stays in the same job level in two consecutive years. Upper jobs correspond to higher slopes by assumption. Thus, the induced wage growth is positively related with the job considered. When the worker changes jobs, the job assignment effect is related with the distance between the slopes $c_{j}$ and $c_{j+1}$. Thus, the wage growth due to this effect can be increasing or decreasing along the job ladder.

Finally, the learning effect is due to the distance between the expected innate ability in a given period and its update in the following period. More optimistic (pessimistic) updates will correspond to higher (lower) wage growth. In the case where the expected ability decreases - a pessimistic update - the learning effect is negative and induces a negative wage growth. The interaction with the other two effects can result in a positive or negative wage growth. Specifically, if the negative learning effect is stronger than the human capital accumulation effect, then the wage growth is negative. Moreover, if the negative effect is strong enough, then the worker can be demoted to a lower job level and the associated wage growth will always be negative. There is no relationship between the learning effect and the worker's position in the hierarchical ladder, but it is more plausible to find a decreasing 
learning effect - as the worker progresses inside the firm, there is less to be learned about his or her ability.

The three effects can interact in different ways, giving rise to a wage-career relationship. Past evidence is scarce, but points to an increasing wage growth upon promotion up the job ladder ${ }^{6}$ This relationship can be explained by an increasing and dominant job assignment effect, in which it becomes disproportionately more difficult to climb the job ladder. That is, the distance between the slopes in the production function becomes greater with the job level. This implies that the individual productivity becomes disproportionately more sensitive to the worker's expected effective ability and that the distance between the cut-off levels increases with the job level. ${ }^{\text {Q }}$ The increasing wage growth rates imply that the human capital accumulation and the learning effects are not sufficiently strong to impair the job assignment effect.

Other cases of interaction between the three effects are possible. For example, a U-shaped relationship in the wage growth due to promotion, that is, high wage growth at the bottom job levels and at the top, and lower wage growth in the middle of the job ladder, can be the result of several combinations of the effects. $\mathrm{B}$ One possible combination is rather intuitive. On the one hand, when the inexperienced workers enter a firm, they are frequently subjected to intensive training, which, in the model, would imply a strong human capital accumulation effect at the first stages of the working life. On the other hand, the firm engages in a screening process to select the best workers to retain, which, in the model, can be captured by a strong learning

\footnotetext{
${ }^{6}$ Baker, Gibbs and Holmostrom (1994a) found an increasing wage premium for promotion. Eriksson (1999) also found an increasing wage difference for executives in multiple firms, using Danish data.

${ }^{7}$ This means that it gets more difficult to climb the job ladder, as fewer workers are promoted to higher ranks. The consequence is a hierarchy with a pyramidal structure.

${ }^{8}$ That is why more than three job levels are needed. With three job levels there are only two promotions and two corresponding wage increases. In consequence, there are three possible relationships between the wage increases upon promotion and the job levels - constant, decreasing or increasing.
} 
effect. If the inexperienced new employees are placed at the bottom ranks of the hierarchy, the final result would be a large wage increase when the worker receives the first promotion and leaves the state of "new employee". Thereafter, both effects are decreasing and, in consequence, the wage growth upon promotion is smaller. The job assignment effect in the form described in the last paragraph will eventually become the dominant effect at the middle of the hierarchy, and the wage growth starts to increase in size.

\section{Empirical Specification}

The model presented above can be used for empirical analysis with some modifications to allow estimation. Consider the following wage regression

$$
w_{i t}=\alpha_{i}+\phi_{i k}+z_{i t} \beta+u_{i t},
$$

where $w_{i t}$ is the employee $i$ 's logarithm of monthly real wage in period $t, z_{i t}$ is the vector of individual and firm characteristics, $\alpha_{i}$ is the employee $i$ 's specific effect, $\phi_{i k}$ is the firm $k$ 's specific effect, and $u_{i t}$ is an i.i.d. error term. The specific effects $\alpha_{i}$ and $\phi_{k}$ are fixed over time and without, therefore, any assumed underlying distribution. The objective is to account for unobservable heterogeneity not captured by the other variables included in the right-hand side of equation (6). This equation is a possible empirical counterpart of equation (3). 
The first-difference can be computed as in equation (4) and (5). The result is a first-difference fixed effect equation for those employees who remain with the same employer in two consecutive years,

$$
w_{i t+1}-w_{i t}=\left(z_{i t+1}-z_{i t}\right) \beta+\left(u_{i t+1}-u_{i t}\right)
$$

The difference in log wages is a function of the time-varying terms in the right-hand side of equation (6) plus an error term. Equation (7) can be estimated by ordinary least squares (OLS) and is a consistent estimation method for identifying the effects of time-varying characteristics for those workers who remain in the same firm in two consecutive years. ${ }^{0}$ The time-varying variables are tenure (squared), the career events, time of work, and total number of workers (other firm characteristics show no or almost no variation). The estimation of the first-difference equation is the more appropriate way to investigate the determinants of individual wage growth. A simple wage level equation, even if estimated by some other model for panel data, does not allow a clear definition of the workers' career events.

Each firm may be confronted with different market conditions, react in different ways, and, probably, have different wage-seniority rules. The objective is to identify wage growth free from these effects and to concentrate on the individual career progression. One way to do it is to calculate a double-difference. First, compute by firm and by year the average wage increase (the difference in log wage) for the

\footnotetext{
${ }^{9}$ There is the problem of independence when one worker appears in the data for three consecutive years or more. The solution was to use OLS, but the variance-covariance matrix of the estimators was obtained with the White/Huber estimator. In this way, the possible correlation between two observations of the same individual is taken into account (see, for example, Greene 2000 or even Stata 1999 for a discussion).

${ }^{10}$ See Abowd, Kramarz and Margolis (1999) for an exposition and application of the related estimation methods.
} 
unpromoted workers who remain in the same job level $j$ from one year to the next, $\bar{\Delta} w$. Consider this to be the firm general wage policy dictated by the market conditions and the usual seniority progression. Second, calculate $\left[w_{i t+1}-w_{i t}\right]-\bar{\Delta} w$ and define this double-difference as the wage premium that the worker receives for his year-to-year career transition. The worker $i$ 's wage premium will replace the firstdifference in the left-hand side of equation (7). Now, the coefficients reflect the covariates effect on wage premiums, that is, the wage growth that can be directly linked to the differences in individual career progressions.

\section{The Data}

The data set used is a sample of firms drawn from the survey Quadros de Pessoal collected annually by the Ministry of Employment. A random sample of firms was drawn, stratified according to economic activity, location, firm's legal form, and number of employees. The sample is a longitudinal matched employer-employee panel of 74 large firms from the manufacturing sector, with more than 500 workers each year and followed between 1991 and 1995. The employment history of all workers in the firm and several firms' characteristics are available. The original sample has 391,618 observations. The information used in this study relies mainly on employees who work in the same firm in two consecutive years $(196,694$ observations). The data appendix shows the details, namely the way the sample was constructed and the summary statistics. Analyzing only larger firms has the advantage

\footnotetext{
${ }^{11}$ Similar to a time-variant firm specific effect captured by the average wage growth of the unpromoted employees who do not change place within the firm.
} 
of allowing the focus on the firms' personnel policies with the guarantee that those policies can be identified. Furthermore, the employer must post the firm's responses (the information on employees) sent to the Ministry of Employment in a public place inside the firm. This opportunity for the employees to check the information considerably reduces the risk of measurement error and increases the confidence in the information contained in the survey.

Central to the analysis is the information concerning job levels, promotions and wages. Job levels are classified using the grade levels reported by the firm. It means that the data supplied by the firm mirrors a hierarchy. Table 1 shows the description of the job levels and the number of employees assigned to each level. Table A5 in the data appendix supplies the full description of the levels. As the employees are followed from one year to the next during the five-year sample, their career path can be identified. Namely, if the employees stayed in the same job level, moved up, or moved down. Exit and entry is also identified, but the focus here is on those individuals who stay in two consecutive years in the same firm. We leave to future research the related issues of inter-firm job mobility.

The second important piece of information is the promotion event. In the survey the employer reports the worker's timing of promotions. The definition of a "promotion" is the employer's responsibility because no supplementary information is given by the norms of the survey (only the headline "date of last promotion"). Table 1 shows the proportion of promoted employees by job level. Over the five-year window $16 \%$ of the employees were promoted. It is important to note that promotion is not necessarily associated with a job change.

So, another aspect of the individual career is known, and in this way promotion or no-promotion can disaggregate the job transitions over the years within firms. The 
data available allow us to recognize not only if the worker changed job levels, but also if he was promoted or not. employee's career path:

- move to an upper job level upon promotion;

- $\quad$ stay in the same job level with a promotion (promotion within job level);

- move to a lower job level upon promotion;

- move to an upper job level without a promotion;

- $\quad$ stay in the same job level without a promotion;

- move to a lower job level without a promotion (demotion).

There is a conceptual problem with the event "move to a lower job level upon promotion". This downward promotion is an unfortunate consequence of not having the true hierarchy but its image shaped by the norms of the survey.

The third piece of information central to the analysis is the individual wage. Wages are reported in the survey for the reference month and were deflated to 1995 constant PTE. The means of log real wages across job levels are presented in the first column of Table 2. Although the issue is not treated in this study, there is some evidence that wages are strongly related to job levels, because the higher the job level, the higher is the average wage. The difference between the mean log wage in two consecutive job levels is large, for example between Level 7 and Level 8 or Level 3 and Level 4. The analysis in the next section will try to explain part of this wage-job variation.

\footnotetext{
${ }^{12}$ The promotion information in this case does not have the usual definition of moving to upper job levels, which is sometimes denominated "vertical promotion". It is more than that since it gives information about the worker's performance as it is perceived by the employer.
} 
The difference in the mean wages between Level 5 and Level 6 is close to zero. From Table A6 in the data appendix, we see that the workers in Level 5 are younger, have less tenure and are better educated than the workers in Level 6. In addition, workers in Level 6 are older and have higher tenure than workers in Level 7 and Level 8. So, although Level 6 appears to be at a higher hierarchical position than Level 5, what is probably occurring is the overlap of two hierarchies. One job level belongs to a more technical career (Level 5), and the other is more related with productive or administrative process (Level 6), where workers with a longer working life in the firm reach jobs with higher responsibility - not necessarily with authority over all the workers in Level 5, but with authority over workers in Level 4 and under (qualified professionals or lower).

Table 2 also presents the mean difference in individual log wages in two consecutive years and the mean difference in log wages for those employees who were not promoted and who remained in the same job level in two consecutive years (calculated by firm and by year). Finally, it presents the mean double difference, the mean of $\left[w_{i t+1}-w_{i t}\right]-\bar{\Delta} w$ defined previously - the mean wage premiums. Observe that the values on these last three columns first decrease and then increase, denoting a U-shape. The econometric analysis will give at least part of the explanation for these patterns.

\section{Econometric Analysis}

Equation (7) is the base for the estimation performed in this section. The objective is to study the employees' wage premium along their career path and the equation is 
estimated by OLS applying several definitions of the variables that capture the career effects. The dependent variable is the individual wage premium defined previously as

$$
\text { worker } i \text { 's wage premium }=\left[w_{i t+1}-w_{i t}\right]-\bar{\Delta} w
$$

where $\bar{\Delta} w$ is the average wage increase by firm and by year (the difference in log real wage) for the unpromoted workers who remain in the same job level $j$ from one year to the next. The information contained in the survey is recorded for a reference month every year. So, for example, the annual wage variation is computed by the difference between the monthly real wage in two consecutive years (the data appendix presents the details).

All the regressions presented include first-differences in tenure squared, log hours and $\log$ number of workers employed in each firm. Tables A7 and A8 in the data appendix show the regressions considering only these variables. The constant is $1 \%$ for the pooled regression and 5\% for the five-year regression and captures all the effects that are decomposed and estimated in this section. The other estimated coefficients experience minor changes in the regressions that follow and are omitted from the tables. Regressions using a sample restricted to workers with change in log hours lower than 0.05 were also estimated and the conclusions of this section remain qualitatively the same. 
Table 3 shows the estimation results for aggregated career effects. In regression (1) and (2) presented in Table $3 a$ the dependent variable is the annual wage premium. The observations are pooled for the five years (four year-to-year transitions). The first regression captures the overall career effect of being promoted, regardless of what the employee job transition is. The results show that the wage premium for a promoted employee is $6 \%$.

The second regression still does not use the information concerning the job levels, but considers the type of transitions with and without promotions. The wage premiums associated with promotion are $9 \%$ if the employee moves up in the job ladder, $4 \%$ if he stays in the same job level, and $5 \%$ if he moves to a lower job level (these last two coefficients are not statistically different). Thus, in spite of moving down, the worker receives a positive wage premium upon promotion. One possible reason is the existence of more than one job ladder inside the firm not fully captured by the job levels reported in the survey. ${ }^{13}$ In any event, these movements are not very frequent, representing fewer than $5 \%$ of all promotions.

Why should firms use promotions within job levels? In the context of the theoretical set-up previously presented, it can be thought of as some workers advancing faster than others inside the job level. If they are identified as higherexpected-ability workers, then their wage growth is higher. Is can also be the case that promotion is given as an incentive, such as in the tournament theory (Lazear and

\footnotetext{
13 Seltzer and Merrett (2000), using the personnel records from a bank, also found positive wage premiums for some movements to lower job levels and argue that these movements are not really demotions, but rather some form of job rotation.
} 
Rosen 1981), where workers compete for a prize, which does not necessarily mean a promotion to a higher job level. 14

The unpromoted workers receive a lower wage premium for the same transitions as the promoted co-workers. The wage premium is $3 \%$ if they move up and close to zero if they move to lower levels. Are demotions associated with negative wage premiums? The disaggregated career effects estimated in the next subsection will highlight this point. The remaining workers are those with no promotion who stay in the same job level (they are the comparison group).

The difference between the wage growth upon promotion or no-promotion shows that firms use promotions to select workers even if they experience the same type of movement within the job ladder. When the worker is promoted, his expected effective ability is valued at a higher rate, as can be seen in equation (5), given that higher job levels correspond to higher slopes of the individual production function (and abstracting from the curvature of the human capital function). Thus, the promoted worker who moves to upper job levels has a larger wage increase than the unpromoted ones who stay in the same job level. At the same time, if the worker receives a promotion, it indicates that he has higher innate ability. This positive learning effect also produces a higher wage premium, and that is why the promoted workers receive larger wage increases when compared to the unpromoted workers who experience the same job movement.

Regressions (3) and (4) in Table 3b use only the employees who stay in the same firm for five years. ${ }^{15}$ The dependent variable in this case is the individual wage

\footnotetext{
${ }^{14}$ Manove (1997) also argues that one way to induce workers' effort is to construct a job ladder, even if the jobs in the different hierarchical layers do not correspond to different responsibility levels. The combination of the promotion motive with incentive wages increases the gains of the employer, in a context of termination contracts.

${ }^{15}$ In these regressions the sample is selected and the results are biased because only the individuals with stable employment attachment of at least five years are used. The same type of problem is present
} 
premium between 1991 and 1995. In regression (3), the wage premium for one more promotion is $5 \%$. Regression (4) is parallel to regression (2), but the total number of transition types are used instead of dummy variables. The results are even sharper than in the pooled regression. One more promotion to an upper level implies a wage premium of $10 \%$ and a move down to a lower job level (demotion) implies a negative wage premium of 5\%. In addition, promoted workers who stay in the same job level receive a higher wage premium than those promoted workers who move down, and the result found in regression (2) disappears - the problem of having promotion downwards is attenuated when the five-year career history is taken into account.

\section{Disaggregated Career Effects}

Regression (5) in Table 4 disaggregates even further the career effects by considering each type of transition and promotion/no-promotion across job levels. In this way the wage premiums along the job ladder are identified. The unpromoted workers who remain in Level 3 are the comparison group because their average wage premium is the lowest found (see Table 2). As before, promotion implies a positive and higher wage premium than no promotion for the same worker's career movement. The workers who move up with a promotion entail the highest wage premiums comparing by job level, though there are some exceptions. There is, once again, the problem of

in the previous regressions, thought of in a mitigating manner, given that the employee has to be at the same firm for only two consecutive years. 
not having the true hierarchy or hierarchies, as the promotion from above to Levels 7 , 6 and 5 entails a higher premium than the promotion from below. 16

The wage premiums are higher in the bottom and in the top ranks, and lower in the middle ranks for promoted workers. The same seems to be true for the workers who move up without a promotion, with the exception of moves to Level 8 . The wage premiums can be considered to be of a U-shape over the career path and this is the more prevalent wage-career relationship among the firms in the sample. As discussed in Section 2, this could be the result of stronger learning and human capital accumulation effects at the bottom and stronger job assignment effect at the top. However, regressions by firm (omitted) show that all cases exist - U-shape, inverse U-shape, increasing, decreasing, and constant (or even no identifiable pattern). It demonstrates that firms do not follow the same personnel policies and the different combinations of the human capital accumulation, job assignment and learning effects can explain the different shapes of the wage-career relationship.

The unpromoted employees who remain in the same job level receive a modest wage premium, or none, at all. Only those who remain in Level 1 receive a positive and important wage premium of $7 \%$. Once again, in the job level where the new hired employees are placed, there is a process of screening and/or an important human capital accumulation effect. The result is a large wage premium even if there is no promotion.

The movements to lower levels without promotion are the job transitions generally considered as demotions. If, in the previous regressions, it was not clear that

\footnotetext{
${ }^{16}$ Furthermore, some components of the employee's compensation are not recorded in the survey, such as credit cards or company cars, and usually they are more important in the top ranks of the hierarchy.

${ }^{17}$ Another possible explanation to have higher wage premiums upon promotion at the top of the hierarchy is provided by Rosen (1986). The author shows that in a tournament with a succession of rounds, the prizes associated with the final rounds have to be higher to maintain the incentives to the winners of past rounds, given that the winner does not expect to receive many more prizes in the future.
} 
demotions were associated with a negative wage premium, the results with the disaggregate career effects indicate precisely where this association can be found. The wage premiums are negative at the bottom, Levels 1 and 2, zero at the top, Levels 6 and 7, and modest (2-3\%) at the middle, Levels 3, 4 and 5. These modest but positive wage premiums probably mean that the movements in the middle of the hierarchy are not really demotions, but lateral or upward moves not captured by the fixed grade levels used to classify jobs. 18

The movements downward at the tails of the hierarchy can be classified as demotions, especially for those workers who move to Level 1 and 2 from upper job levels and receive a negative wage premium. In the context of the model, demotions occur because a strong learning effect of negative sign dominates the human capital accumulation effect and the worker's expected effective ability becomes lower than the cut-off level that determines the assignment to the previous job level. Moreover, it is not surprising that the negative wage premiums were found at the bottom job levels, where the learning effect could be considered to be more important in reality, given that those job levels are filled mainly with workers at the beginning of their working lives at the firm.

What are the consequences of the promotion/no-promotion along the workers' career path? Figure 1 compares two equal workers hired by the firm at the same time and both assigned to Level 1 . The initial wage is equal to the average monthly real wage in Level 1 found in the sample, 65,000 PTE. The only difference in their career progression is that one is promoted every year and the other is never promoted. Both

\footnotetext{
${ }^{18}$ However, as mentioned in footnote 13, Seltzer and Merrett (2000) in a single-firm study also found a similar situation. It can also be the case that the employer wants to retain the worker in spite of the demotion, and in order to do that, does not decrease his real wage. Otherwise, another employer could bid the worker away. Bernhardt (1995), in a similar setting, but assuming asymmetric information, proves that in this case demotions are associated with wage increases.
} 
experience the same job movements: first, they stay two years in Level 1, in the third year they move to Level 2, in the fourth year they stay in Level 2, and so forth until they both reach Level 8 in the fifteenth year (two years in each job level until they reach Level 8). The objective is to show the "pure" promotion effect on wage growth using the results for the disaggregated career effects obtained in Table 4. After five career-years they are both in Level 3 and the promoted worker earns $20 \%$ more than the unpromoted worker. After ten years they are in Level 5 and the difference between their wages is $55 \%$. At the end of the fifteenth year, the promoted worker earns almost twice (93\% more) the unpromoted worker's wage. His wage grew almost $200 \%$ during the period, though the unpromoted worker's wage grew only $46 \%$. These results show the implications of the estimation performed in Table 4: firms select their workers through promotions.

\section{Extensions}

There are several possible ways to extend the analysis of wage growth within firms. For one thing, the evidence presented by Baker, Gibbs and Holmostrom $(1994 a, b)$ for one firm can be extended to the multi-firm case. Preliminary analysis was made (computing simple correlation coefficients) to determine if wage increases are serially correlated and if wage increases are correlated with future promotions. These relationships are predictions from the model presented in Section 2 and are due to the interaction of innate ability with the human capital accumulation, which implies that the more able receive higher wage increases and are promoted first. The preliminary 
results seem to confirm these predictions. The evidence is omitted because more work is needed to fully identify these relationships in the data set used here.

Another prediction from the model is that promoted workers are expected to move from the top of the wage distribution in the job level prior to promotion and arrive at the bottom of the wage distribution in the job level after promotion, though this does not hold true for all workers. Previous analysis made with data for one firm belonging to the sample confirmed this result. In the case of the multi-firm data analyzed in the present study, the calculations have to be made by firm, year, job level, and career event, and is a subject to be developed in future research.

\section{Conclusion}

The present essay proposed to study the wage-career relationship in detail. An economic model of internal working of firms was first presented to guide the empirical analysis. The data available proved to be suitable for testing the theoretical results and for comparing with applied results from other studies. The panel of multifirms used is by itself a guarantee of some novelty, but the results presented here add new insights to the study of the firms' personnel policies. The information regarding the year-to-year job transitions and promotions allowed us to observe the nature of the relationship between the workers' wage growth and their career path within firms.

Overall, firms select workers through decisions concerning their career path. Promotions and/or transitions to upper job levels imply a positive and important wage

\footnotetext{
${ }^{19}$ See, for example, Chiappori, Salanié and Valentin (1999) who, in a related setting, show how the wage and promotion paths can be used to overcome the lack of individual performance measures, and Farber and Gibbons (1996) on wage dynamics.
} 
premium. Demotions are associated with negative wage premiums. The negative wage premiums are more important at the bottom job levels, probably as a result of the (negative) learning effect.

The wage premiums for promotions are higher at the tails of the hierarchy, generating a U-shaped relationship between the workers' career path and wage growth. This shape is the more prevalent one for the set of firms. In the context of the model discussed, it suggests a stronger learning and/or human capital accumulation effect at the bottom of the hierarchy and a stronger job assignment effect at the top. Nevertheless, firms can have different personnel policies concerning careers and wage premiums, as a firm-by-firm analysis confirms. Namely, inverse U-shape, increasing, decreasing, and constant (or even no identifiable pattern) relationships can be found. It would be interesting to explore this line of research and find identifiable firm characteristics that determine this relationship.

There are several possible extensions to perform in future research aside from those already mentioned in the last section. The wage premium equation can be estimated separately by level of education to better understand the effects of this worker's observable characteristic. The issue of gender differences can also be studied in the same manner. The workers' transitions between firms were not the focus of this paper, but there are several results from the available literature that can be explored with the data set constructed from the survey Quadros de Pessoal. 


\section{Data Appendix}

Table A1 presents the distribution of workers across several firms' characteristics. These firms represent roughly $60 \%$ of all the individuals working in firms with the same characteristics in the economy - manufacturing sector and with more than 500 workers per year. The average number of workers in each firm is 1,681 . For the five years, the lowest firm has roughly 2,500 workers, and the largest has more than 20,000 workers. Firms from the industry of textiles, clothing, leather, and footwear employ the greatest number of workers. This industry is traditionally a very important economic activity in Portugal. Workers employed by the firms in the sample are concentrated in the North and Lisbon and the predominant legal type is the corporation.

Tables A2-A4 present the summary statistics. The unit of observation is the employee and, as a consequence, all other workers - employers and unpaid family workers - are excluded from the analysis (1,519 observations). Employees without identification number cannot be followed and are also excluded (14,524 observations). The variables are for the reference month. The reference month is March up until 1993. Following this year the reference month is October. This fact introduces a problem with the timing of the variables - the 1994 values were obtained more than one year after the 1993 values. Thus, a special care must be taken whenever addressing yearly change in the variables.

Those employees with zero earnings are excluded (18,288 observations). The zero earnings exclusion is equivalent to zero working hours exclusion in this sample. As this variable is prone to having a measurement error, a simple wage regression was estimated (omitted) to identify possible outliers. The rule was to exclude observations 
with wages outside an interval defined by five times the standard error around the predicted value (1,003 observations). The employee-year observations with missing education, tenure and prior work experience are excluded (13,800 observations). The final sample size also excludes employees younger than 15 years old, those born before 1925, and those with tenure higher than age (340 observations).

\section{References}

Abowd, John M.; Kramarz, Francis; and Margolis, David N. "High Wage Workers and High Wage Firms.” Econometrica 67 (March 1999): 251-333.

Baker, George; Gibbs, Michael; and Holmstrom, Bengt. "The Internal Economics of the Firm: Evidence from Personnel Data." Quarterly Journal of Economics 109 (November 1994): 881-919. (a)

. "The Wage Policy of a Firm." Quarterly Journal of Economics 109

(November 1994): 921-955. (b)

Bernhardt, Dan. "Strategic Promotion and Compensation." Review of Economic Studies 62 (April 1995): 315-339.

Bernhardt, Dan, and Scoones, David. "Promotion, Turnover, and Preemptive Wage Offers.” American Economic Review 83 (September 1993): 771-791.

Chiappori, Pierre-André; Salanié, Bernard; and Valentin, Julie. "Early Starters versus Late Beginners.” Journal of Political Economy 107 (August 1999): 731-760.

Eriksson, Tor. "Executive Compensation and Tournament Theory: Empirical Tests on Danish Data.” Journal of Labor Economics 17 (April 1999): 262-280. 
Farber, Henry S., and Gibbons, Robert. "Learning and Wage Dynamics." Quarterly Journal of Economics 111 (November 1996): 1007-1047.

Gibbons, Robert. "Incentives and Careers in Organizations." In Advances in Economic Theory and Econometrics, edited by David Kreps and Ken Wallis, 137. New York: Cambridge University Press, 1997.

Gibbons, Robert, and Waldman, Michael. "A Theory of Wage Promotions Dynamics Inside Firms." Quarterly Journal of Economics 114 (November 1999): 13211358. (a) . "Careers in Organizations: Theory and Evidence." In Handbook of Labor Economics, edited by Orley Ashenfelter and David Card, 2373-2437. Amsterdam: Elsevier, 1999. (b)

Greene, William H. Econometric Analysis. New Jersey: Prentice-Hall, 2000.

Jovanovic, Boyan. "Job Matching and the Theory of Turnover." Journal of Political Economy 87 (October 1979): 972-990.

Kahn, Charles, and Huberman, Gur. "Two-sided Uncertainty and 'Up-or-Out' Contracts." Journal of Labor Economics 6 (October 1988): 423-444.

Lazear, Edward P. "Personnel Economics: Past Lessons and Future Directions." Journal of Labor Economics 17 (April 1999): 199-236.

Lazear, Edward P., and Rosen, Sherwin. "Rank-Order Tournaments as Optimal Labor Contracts.” Journal of Political Economy 89 (October 1981): 841-864.

Manove, Michael. "Job Responsibility, Pay and Promotions." The Economic Journal 107 (January 1997): 85-103.

McCue, Kristin. "Promotions and Wage Growth." Journal of Labor Economics 14 (April 1996): 175-209. 
Milgrom, Paul, and Oster, Sharon. "Job Discrimination, Market Forces and the Invisibility Hypothesis." Quarterly Journal of Economics 102 (August 1987): 453-476.

Pergamit, Michael R., and Veum, Jonathan R. "What is a promotion?" Industrial and Labor Relations Review 52 (July 1999): 581-601.

Prendergast, Canice. "The Provision of Incentives in Firms." Journal of Economic Literature 37 (March 1999): 7-63.

Ricart I Costa, Joan E. “Managerial Task Assignment and Promotions.” Econometrica 56 (March 1988): 449-466.

Rosen, Sherwin. "Prizes and Incentives in Elimination Tournaments." American Economic Review 76 (September 1986): 701-715.

Sattinger, Michael. "Comparative Advantage and the Distribution of Earnings and Abilities." Econometrica 43 (May 1975): 455-468.

Seltzer, Andrew, and Merrett, David. "Personnel Policies at the Union Bank of Australia: Evidence from the 1888-1900 Entry Cohorts." Journal of Labor Economics 18 (October 2000): 573-613.

StataCorp. Stata Statistical Software: Release 6.0. College Station, TX: Stata Corporation 1999.

Waldman, Michael. "Worker Allocation, Hierarchies and the Wage Distribution." Review of Economic Studies 51 (January 1984): 95-109. (a) . "Job Assignments, Signalling, and Efficiency." Rand Journal of Economics 15 (Summer 1984): 255-267. (b) . "Up-or-Out Contracts: A Signaling Perspective." Journal of Labor Economics 8 (April 1990): 230-250. 
Table 1. Job levels and promotion for employees working two consecutive years at the same firm

\begin{tabular}{llrrr}
\hline \hline Job Level & Description & Employees & $\%$ & $\%$ promoted \\
\hline Level 1 & Apprentices, interns, trainees & 3,975 & 2.02 & 34.59 \\
Level 2 & Non-qualified professionals & 11,316 & 5.75 & 14.67 \\
Level 3 & Semi-qualified professionals & 66,275 & 33.69 & 16.10 \\
Level 4 & Qualified professionals & 74,123 & 37.68 & 14.36 \\
Level 5 & Higher qualified professionals & 15,052 & 7.65 & 15.28 \\
Level 6 & Supervisors, team leaders, foremen & 13,107 & 6.66 & 12.76 \\
Level 7 & Intermediary executives & 6,506 & 3.31 & 19.37 \\
Level 8 & Top executives & 6,340 & 3.22 & 15.35 \\
\hline Total & & 196,694 & 100.00 & 15.54 \\
\hline \hline
\end{tabular}


Table 2. Wage information

\begin{tabular}{lrrrr}
\hline \hline Job Level & Mean log wages & $\begin{array}{r}\text { Mean difference in } \\
\text { individual log } \\
\text { wages in two } \\
\text { consecutive years }\end{array}$ & $\begin{array}{r}\text { Mean difference in } \\
\text { log wages for } \\
\text { unpromoted job } \\
\text { level stayers }\end{array}$ & $\begin{array}{r}\text { Mean wage } \\
\text { premium }\end{array}$ \\
\hline Level 1 & 11.16 & 9.31 & 3.68 & 3.48 \\
Level 2 & 11.27 & 3.29 & 2.42 & 1.11 \\
Level 3 & 11.30 & 0.48 & 0.10 & 0.69 \\
Level 4 & 11.61 & 2.06 & 1.64 & 0.68 \\
Level 5 & 12.04 & 2.54 & 1.04 & 1.55 \\
Level 6 & 12.04 & 2.56 & 1.61 & 1.29 \\
Level 7 & 12.46 & 3.57 & 1.32 & 2.67 \\
Level 8 & 12.92 & 5.10 & 1.74 & 3.40 \\
\hline Total & 11.61 & 1.97 & 1.13 & 1.02 \\
\hline \hline
\end{tabular}

Data for monthly real wages (constant 1995 PTE). Values multiplied by 100 except the mean log wages. Data for employees working two consecutive years at the same firm. Wage premium is defined as the double-difference between the change in individual log real wage and the average change by year and by firm in log real wage of the unpromoted workers who stay in the same job level in two consecutive years. 
Table 3a. Wage premium (pooled) regressions - aggregated career effects

Dependent variable: annual real wage premium (unit of analysis = employee-year)

Independent variables

Coefficient

Standard error

Regression (1)

Promotion (dummy)

5.51

Constant

0.49

$R$-squared

$F$ statistic

Regression (2)

Transitions with promotion (dummies)

Move to upper levels

Stay in the level

Move to lower levels

Transitions without promotion (dummies)

Move to upper levels

Move to lower levels

Constant

0.31

0.06

$R$-squared

$F$ statistic

All employees working two consecutive years at the same firm included in the estimation. Values multiplied by 100. An asterisk marks the coefficients where the null hypothesis (equal to zero) cannot be rejected at the $10 \%$ level. All the other coefficients presented are significant at $1 \%$ level. All the regressions are globally significant. The regressions also include first-differences in tenure squared, log hours and log number of workers employed in each firm. 
Table $3 \mathrm{~b}$. Wage premium regressions - aggregated career effects

Dependent variable: real wage premium between 1991 and 1995

Independent variables

Coefficient Standard error

Regression (3)

Total number of promotions

5.18

0.14

Constant

1.79

$R$-squared

$F$ statistic

Regression (4)

Total number of transitions with promotion

Move to upper levels

10.32

0.38

Stay in the level

Move to lower levels

2.36

Total number of transitions without promotion

Move to upper levels

Move to lower levels

Constant

Number of observations

Only the employees working for the five years at the same firm included in the estimation. Values multiplied by 100. All coefficients are significant at $1 \%$ level. All the regressions are globally significant. The regressions also include first-differences in tenure squared, log hours and log number of workers employed in each firm. 
Table 4. Wage premium (pooled) regression - disaggregated career effects

Dependent variable: real wage premium (unit of analysis = employee-year)

Regression (5)

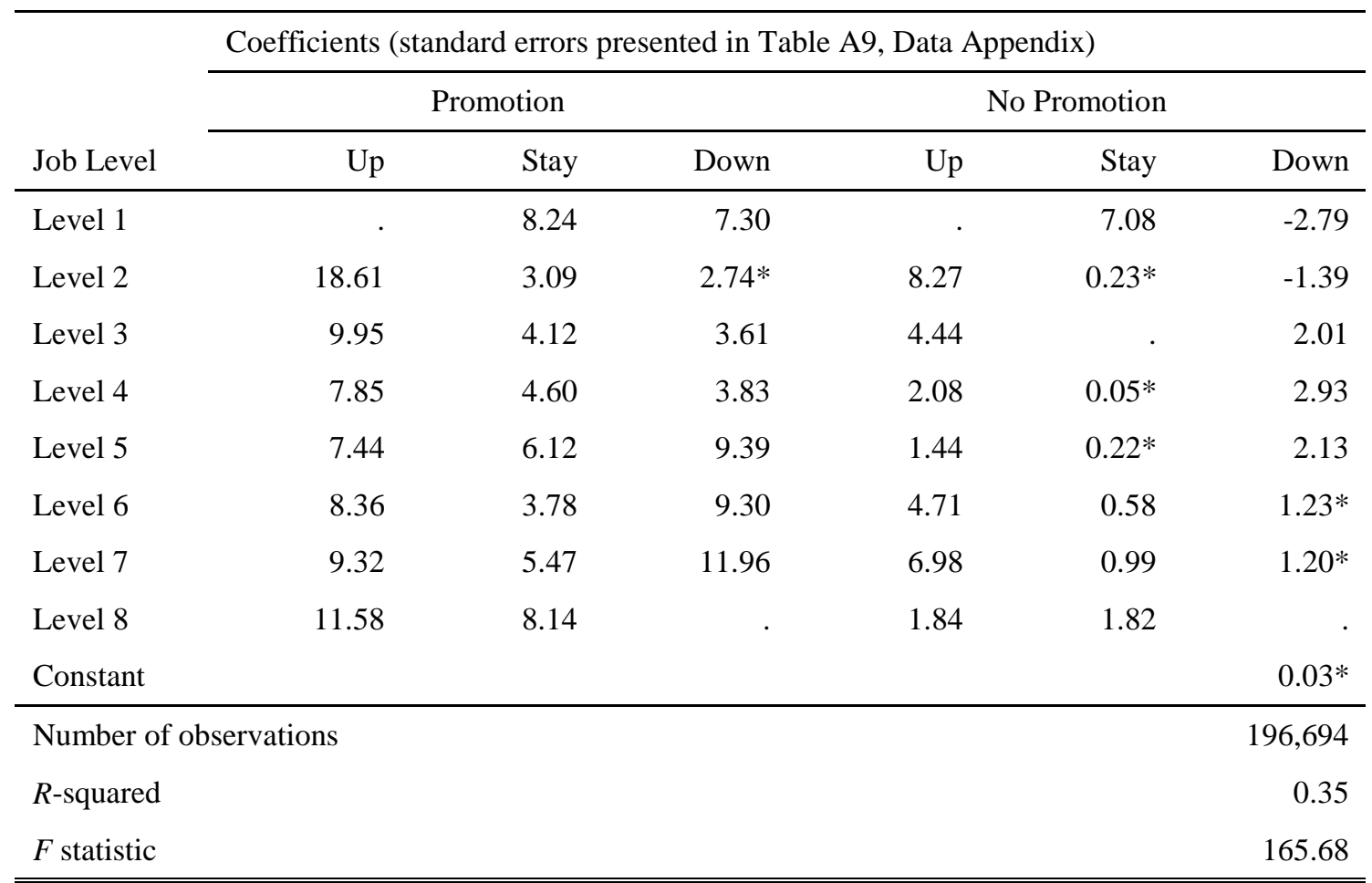

All employees working two consecutive years at the same firm included in the estimation. Values multiplied by 100. An asterisk marks the coefficients where the null hypothesis (equal to zero) cannot be rejected at the $10 \%$ level. The regression is globally significant. Unpromoted employees who stay in Level 3 are the base category. The regression also includes first-differences in tenure squared, log hours and log number of workers employed in each firm. 
Table A1. Distribution of workers across firms - selected characteristics

\begin{tabular}{lrr}
\hline \hline Variable & Mean & Standard deviation \\
\hline Number of workers & $1,680.58$ & $1,329.05$ \\
$\quad$ Dummies for industry & & 0.26 \\
Food, beverages and tobacco & 0.07 & 0.49 \\
Textiles, clothing, leather, and footwear & 0.40 & 0.15 \\
Wood and cork & 0.02 & 0.21 \\
Paper, printing and publishing & 0.05 & 0.29 \\
Chemical products & 0.09 & 0.26 \\
Non-metal products & 0.08 & 0.45 \\
Machinery and equipment & 0.29 & 0.50 \\
$\quad$ Dummies for region & & 0.48 \\
North & 0.49 & 0.34 \\
Other & 0.37 & 326,975 \\
Corporations & 0.14 & 0.49 \\
Proprietorship & & 0.49 \\
Other & 0.60 & 0.14 \\
\hline \hline
\end{tabular}


Table A2. Summary statistics - all workers

\begin{tabular}{|c|c|c|c|c|}
\hline Variable & Mean & $\begin{array}{l}\text { Standard } \\
\text { deviation }\end{array}$ & Minimum & Maximum \\
\hline Dummy for hours worked $<30$ & 0.0428 & 0.2024 & 0 & 1 \\
\hline Tenure & 13.4591 & 9.6264 & 0 & 53 \\
\hline Tenure squared & 273.8146 & 311.9219 & 0 & 2,809 \\
\hline Prior work experience & 11.6668 & 8.1033 & 0 & 57 \\
\hline Prior work experience squared & 201.7766 & 266.9608 & 0 & 3,249 \\
\hline Age & 37.4877 & 10.9064 & 15 & 69 \\
\hline Dummy for female & 0.4305 & 0.4951 & 0 & 1 \\
\hline Dummy for bargaining regime & 0.1278 & 0.3340 & 0 & 1 \\
\hline \multicolumn{5}{|c|}{ Dummies for level of education } \\
\hline Lower Primary & 0.4517 & 0.4977 & 0 & 1 \\
\hline Upper Primary & 0.2324 & 0.4224 & 0 & 1 \\
\hline Lower Secondary & 0.1005 & 0.3007 & 0 & 1 \\
\hline Upper Secondary & 0.1273 & 0.3333 & 0 & 1 \\
\hline Tertiary (3 years) & 0.0158 & 0.1248 & 0 & 1 \\
\hline Tertiary (5 years) & 0.0275 & 0.1635 & 0 & 1 \\
\hline Number of observations & & & & 326,975 \\
\hline
\end{tabular}

Bargaining regime: dummy variable equal to zero if the bargain is at the sector level (the most frequent regime), and equal to one if another regime is used (single-firm, multi-firm or government compulsory regime). 
Table A3. Summary statistics for employees with two consecutive years at the same firm

\begin{tabular}{|c|c|c|c|c|}
\hline & Mean & $\begin{array}{l}\text { Standard } \\
\text { deviation }\end{array}$ & Minimum & Maximum \\
\hline Difference in log real wage & 0.0195 & 0.2890 & -3.3626 & 3.2982 \\
\hline Wage premium & 0.0101 & 0.2729 & -3.3843 & 3.2861 \\
\hline tenure squared & 27.1158 & 64.9297 & -2960 & 3311 \\
\hline log hours worked & -0.0047 & 0.2524 & -4.4308 & 5.2149 \\
\hline $\log$ number of workers & -0.0429 & 0.1232 & -0.7640 & 1.0136 \\
\hline \multicolumn{5}{|l|}{ Dummies for career } \\
\hline Promotion & 0.1554 & 0.3623 & 0 & 1 \\
\hline \multicolumn{5}{|l|}{ Transitions with promotion } \\
\hline Move to upper levels & 0.0401 & 0.1962 & 0 & 1 \\
\hline Stay in the level & 0.1078 & 0.3101 & 0 & 1 \\
\hline Move to lower levels & 0.0075 & 0.0862 & 0 & 1 \\
\hline \multicolumn{5}{|l|}{ Transitions without promotion } \\
\hline Move to upper levels & 0.0435 & 0.2040 & 0 & 1 \\
\hline Stay in the level & 0.7727 & 0.4191 & 0 & 1 \\
\hline Move to lower levels & 0.0285 & 0.1664 & 0 & 1 \\
\hline Number of observations & & & & 196,694 \\
\hline
\end{tabular}


Table A4. Summary statistics for employees with five consecutive years at the same firm

\begin{tabular}{|c|c|c|c|c|}
\hline & Mean & $\begin{array}{l}\text { Standard } \\
\text { deviation }\end{array}$ & Minimum & Maximum \\
\hline Difference in log real wage & 0.0886 & 0.2900 & -3.4188 & 2.8593 \\
\hline Wage premium & 0.0375 & 0.2727 & -3.3926 & 2.6720 \\
\hline tenure squared & 117.8573 & 90.6056 & -2580 & 980 \\
\hline log hours worked & -0.0063 & 0.2443 & -3.6428 & 3.8712 \\
\hline $\log$ number of workers & -0.1974 & 0.2788 & -0.9053 & 0.9461 \\
\hline \multicolumn{5}{|l|}{ Dummies for career } \\
\hline Total number of promotions & 0.6113 & 0.9496 & 0 & 4 \\
\hline \multicolumn{5}{|c|}{ Total number of transitions with promotion } \\
\hline Move to upper levels & 0.1341 & 0.3549 & 0 & 3 \\
\hline Stay in the level & 0.4460 & 0.8478 & 0 & 4 \\
\hline Move to lower levels & 0.0312 & 0.1749 & 0 & 2 \\
\hline \multicolumn{5}{|c|}{ Total number of transitions without promotion } \\
\hline Move to upper levels & 0.1330 & 0.3700 & 0 & 2 \\
\hline Stay in the level & 3.1588 & 1.0732 & 0 & 4 \\
\hline Move to lower levels & 0.0969 & 0.3290 & 0 & 3 \\
\hline Number of observations & & & & 27,267 \\
\hline
\end{tabular}


Table A5. Job Levels (Grade Levels as defined by law - Decreto Lei 121/78 of July 2)

\begin{tabular}{|c|c|c|}
\hline Level & Tasks & Skills \\
\hline $\begin{array}{l}8-\text { Top executives (top } \\
\text { management) }\end{array}$ & $\begin{array}{l}\text { Definition of the firm general } \\
\text { policy or consulting on the } \\
\text { organization of the firm. } \\
\text { Strategic planning. } \\
\text { Creation or adaptation of } \\
\text { technical, scientific and } \\
\text { administrative methods or } \\
\text { processes. }\end{array}$ & $\begin{array}{l}\text { Knowledge of management and } \\
\text { coordination of firm's } \\
\text { fundamental activities. } \\
\text { Knowledge of management and } \\
\text { coordination of the fundamental } \\
\text { activities in the field to which } \\
\text { the individual is assigned and } \\
\text { that requires the study and } \\
\text { research of high responsibility } \\
\text { and technical level problems. }\end{array}$ \\
\hline $\begin{array}{l}7 \text { - Intermediary executives } \\
\text { (middle management) }\end{array}$ & $\begin{array}{l}\text { Organization and adaptation of } \\
\text { the guidelines established by the } \\
\text { superiors and directly linked } \\
\text { with the executive work. }\end{array}$ & $\begin{array}{l}\text { Technical and professional } \\
\text { qualifications directed to } \\
\text { executive, research, and } \\
\text { management work. }\end{array}$ \\
\hline $\begin{array}{l}6 \text { - Supervisors, team leaders, } \\
\text { foremen }\end{array}$ & $\begin{array}{l}\text { Orientation of teams, as directed } \\
\text { by the superiors, but requiring } \\
\text { the knowledge of action } \\
\text { processes. }\end{array}$ & $\begin{array}{l}\text { Complete professional } \\
\text { qualification with a } \\
\text { specialization. }\end{array}$ \\
\hline 5 - Higher-skilled professionals & $\begin{array}{l}\text { Tasks requiring a high technical } \\
\text { value and defined in general } \\
\text { terms by the superiors. }\end{array}$ & $\begin{array}{l}\text { Complete professional } \\
\text { qualification with a } \\
\text { specialization adding to } \\
\text { theoretical and applied } \\
\text { knowledge. }\end{array}$ \\
\hline $4-$ Skilled professionals & $\begin{array}{l}\text { Complex or delicate tasks and } \\
\text { usually not repetitive and } \\
\text { defined by the superiors. }\end{array}$ & $\begin{array}{l}\text { Complete professional } \\
\text { qualification implying } \\
\text { theoretical and applied } \\
\text { knowledge. }\end{array}$ \\
\hline 3 -Semi-skilled professionals & $\begin{array}{l}\text { Well defined tasks, mainly } \\
\text { manual or mechanical (no } \\
\text { intellectual work) with low } \\
\text { complexity, usually routine and } \\
\text { sometimes repetitive. }\end{array}$ & $\begin{array}{l}\text { Professional qualification in a } \\
\text { limited field or practical and } \\
\text { elementary professional } \\
\text { knowledge. }\end{array}$ \\
\hline 2 - Non-skilled professionals & $\begin{array}{l}\text { Simple tasks and totally } \\
\text { determined. }\end{array}$ & $\begin{array}{l}\text { Practical knowledge and easily } \\
\text { acquired in a short time. }\end{array}$ \\
\hline $\begin{array}{l}1 \text { - Apprentices, interns, } \\
\text { trainees }\end{array}$ & Apprenticeship & \\
\hline
\end{tabular}


Table A6. Means and standard deviations across job levels for selected variables

\begin{tabular}{|c|c|c|c|c|c|c|c|c|}
\hline \multirow[b]{2}{*}{ Variables } & \multicolumn{8}{|c|}{ Job level } \\
\hline & 1 & 2 & 3 & 4 & 5 & 6 & 7 & 8 \\
\hline \multirow[t]{2}{*}{ Education } & 6.29 & 4.65 & 5.11 & 5.97 & 8.53 & 7.03 & 11.16 & 14.02 \\
\hline & 2.44 & 2.53 & 2.49 & 2.97 & 3.51 & 3.50 & 3.70 & 3.04 \\
\hline \multirow[t]{2}{*}{ Tenure } & 2.02 & 10.05 & 12.00 & 14.42 & 16.57 & 19.49 & 16.44 & 14.01 \\
\hline & 3.56 & 9.05 & 9.28 & 9.03 & 8.80 & 9.65 & 10.44 & 9.98 \\
\hline \multirow[t]{2}{*}{ Prior work experience } & 9.12 & 14.81 & 11.77 & 12.17 & 10.31 & 11.40 & 8.41 & 8.72 \\
\hline & 7.11 & 9.85 & 8.00 & 8.06 & 7.08 & 7.65 & 6.37 & 7.07 \\
\hline \multirow[t]{2}{*}{ Age } & 23.63 & 35.73 & 35.09 & 38.65 & 41.43 & 44.15 & 42.07 & 42.73 \\
\hline & 6.83 & 11.61 & 10.58 & 10.17 & 8.61 & 9.31 & 9.57 & 9.63 \\
\hline
\end{tabular}

Number of observations $=326,975$. Standard deviations underneath the means. 
Table A7. Wage premium regressions without career information (pooled)

\begin{tabular}{lrr}
\hline $\begin{array}{l}\text { Dependent variable: real wage premium (unit of analysis = employee-year) } \\
\text { Independent variables (first difference) }\end{array}$ & Coefficient & Standard error \\
\hline tenure squared $\times 10^{-2}$ & -0.37 & 0.13 \\
log hours worked & 63.11 & 0.95 \\
log total number of workers & -0.58 & 0.46 \\
Constant & 1.39 & 0.05 \\
\hline Number of observations & & 196,694 \\
$R$-squared & & 0.34 \\
$F$ statistic & & $1,479.16$ \\
\hline
\end{tabular}

All employees working two consecutive years at the same firm included in the estimation. Values multiplied by 100. All coefficients are significant at $1 \%$ level. The regression is globally significant. 
Table A8. Wage premium regressions without career information

\begin{tabular}{lrr}
\hline \hline Dependent variable: real wage premium between 1991 and 1995 & \\
Independent variables (5-year first difference) & Coefficient & Standard error \\
\hline tenure squared $\times 10^{-2}$ & -1.51 & 0.16 \\
log hours worked & 62.15 & 0.56 \\
log total number of workers & -2.94 & 0.51 \\
Constant & 5.34 & 0.23 \\
\hline Number of observations & & 27,267 \\
Adjusted $R$-squared & & 0.31 \\
$F$ statistic & & $4,114.58$ \\
\hline \hline
\end{tabular}

Only the employees working five years at the same firm included in the estimation. Values multiplied by 100. All coefficients are significant at $1 \%$ level. The regression is globally significant. 
Table A9. Standard errors from the wage premium regression in Table 4

Dependent variable: real wage premium (unit of analysis = employee-year)

Regression (5)

\begin{tabular}{lrrrrrr}
\hline & \multicolumn{3}{c}{ Promotion } & \multicolumn{3}{c}{ No Promotion } \\
\cline { 2 - 7 } Level 1 & Up & Stay & Down & Up & Stay & Down \\
\cline { 2 - 7 } Level 2 &. & 0.68 & 1.42 & $\cdot$ & 0.55 & 0.80 \\
Level 3 & 1.47 & 0.80 & 2.06 & 3.00 & 0.22 & 0.77 \\
Level 4 & 0.55 & 0.22 & 1.02 & 0.47 &. & 0.58 \\
Level 5 & 0.57 & 0.23 & 0.73 & 0.40 & 0.09 & 0.87 \\
Level 6 & 0.64 & 0.53 & 1.23 & 0.63 & 0.15 & 1.15 \\
Level 7 & 0.67 & 0.60 & 2.00 & 0.77 & 0.15 & 0.86 \\
Level 8 & 0.73 & 0.85 & 3.60 & 1.16 & 0.22 & 2.42 \\
Constant & 1.13 & 1.32 & & 1.20 & 0.32 &. \\
\hline \hline
\end{tabular}

All employees working two consecutive years at the same firm included in the estimation. Values multiplied by 100. The regression is globally significant. Unpromoted employees who stay in Level 2 are the base category. The regression also includes first-differences in tenure squared, log hours and log number of workers employed in each firm. 


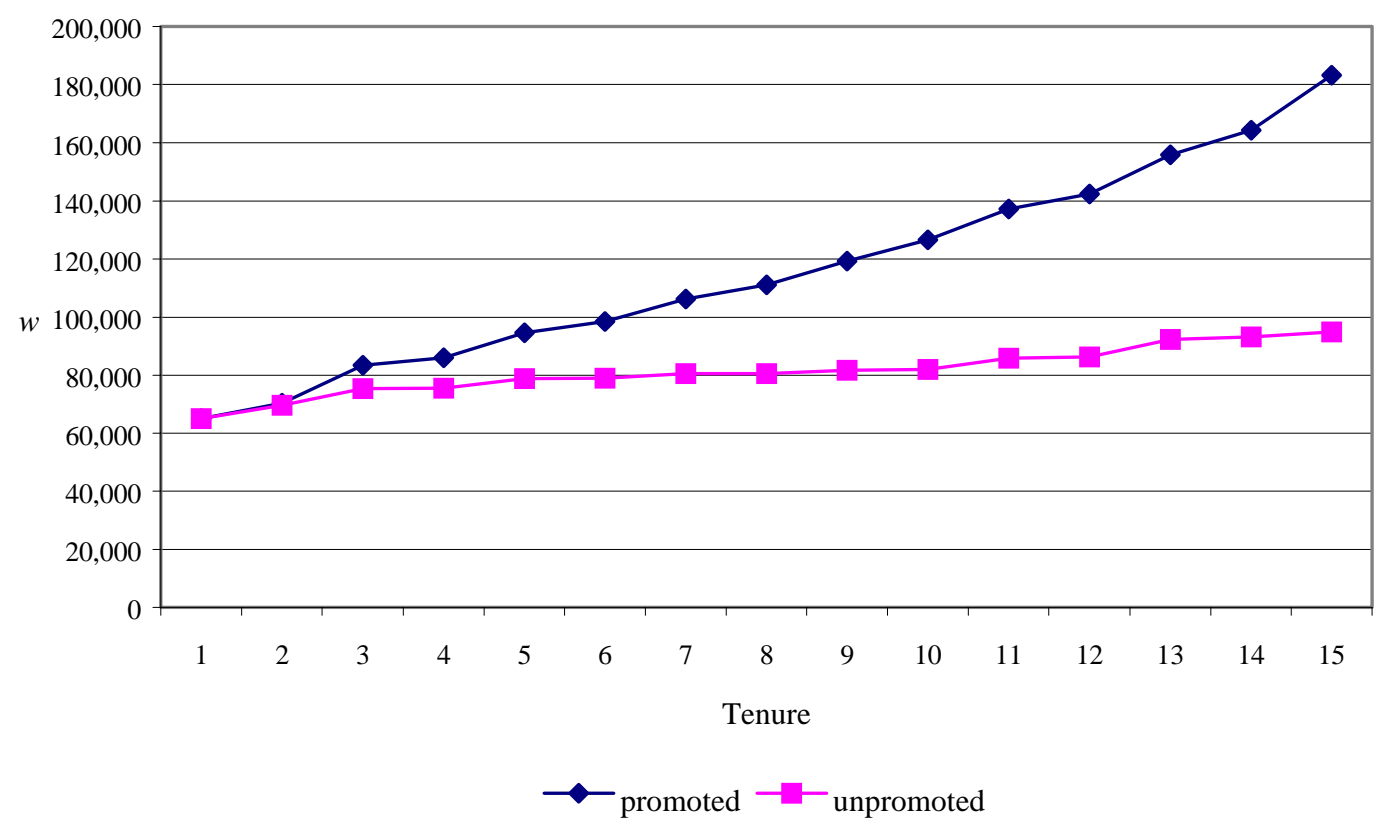

Fig. 1. Selection of stars - wage-career profiles for promoted and unpromoted workers 


\section{IZA Discussion Papers}

No Author(s)

260

M. Lindahl

262

M. Lindahl

263

264

C. Dustmann

265

266

M. Rosholm

M. Svarer

C. Dustmann

O. Kirchkamp

267 A. Newell

A. Newell

B. Reilly

269

H. Buddelmeyer

270

B. Augurzky

C. M. Schmidt

271

B. Augurzky

C. M. Schmidt

272 C. Belzil

J. Hansen
Titel

Area

Date

Temporary Jobs, Employment Protection and

$1 / 3$

$02 / 01$

Labor Market Performance

Home versus School Learning:

5

02/01

A New Approach to Estimating the Effect of Class

Size on Achievement

Summer Learning and the Effect of Schooling:

5

$02 / 01$

Evidence from Sweden

Children and Career Interruptions:

5

$02 / 01$

The Family Gap in Denmark

Return Migration, Wage Differentials, and the

02/01

Optimal Migration Duration

Structurally Dependent Competing Risks

$02 / 01$

The Optimal Migration Duration and Activity Choice after Re-migration

The Distribution of Wages in Transition Countries

4

03/01

The Gender Pay Gap in the Transition from 4

Communism: Some Empirical Evidence

$03 / 01$

Re-employment Dynamics of Disabled Workers

3

03/01

The Evaluation of Community-Based Interventions: 6

$03 / 01$

A Monte Carlo Study

The Propensity Score: A Means to An End

6

03/01

Heterogeneous Returns to Human Capital and 5 Dynamic Self-Selection 

Integration

A. Björklund

S. Vroman

283 M. Hagedorn

A. Kaul

V. Reinthaler

Welfare Analysis in a Schumpeterian Growth Model with Capital 

the Rising Returns to Skill: US and France 19642000

N. Smith

L. Husted 
C. Patxot Monetary Appraisal 
315 W. H. J. Hassink R. Schettkat

316 M. Frondel C. M. Schmidt

317

R. Winkelmann

318 M. Pannenberg

G. G. Wagner

319 R. Euwals

R. Winkelmann

R. Fahr

U. Sunde

O. Hübler

U. Jirjahn
A. Frederiksen
E. K. Graversen
N. Smith

324

M. Pflüger

325

R. A. Hart

J. R. Malley

U. Woitek

326 J. S. Earle

Á. Telegdy

H. Gersbach

A. Schmutzler

328
On Price-Setting for Identical Products in Markets without Formal Trade Barriers

Rejecting Capital-Skill Complementarity at all Costs 5

$06 / 01$

Health Care Reform and the Number of Doctor 7 Visits - An Econometric Analysis

Overtime Work, Overtime Compensation and the 1

06/01 Distribution of Economic Well-Being: Evidence for West Germany and Great Britain

Why do Firms Train? Empirical Evidence on the 1 06/01 First Labour Market Outcomes of Graduated Apprentices

Strategic Hiring Behavior in Empirical Matching 1 Functions

Is there a Return - Risk Link in Education?

5

$07 / 01$

Works Councils and Collective Bargaining in 1 07/01 Germany: The Impact on Productivity and Wages

Overtime Work, Dual Job Holding and Taxation 1

07/01

Trade, Technology and Labour Markets: Empirical 2 Controversies in the Light of the Jones Model

Real Wages and the Cycle: The View from the 1 Frequency Domain

Privatization and Productivity in Romanian Industry: 4 Evidence from a Comprehensive Enterprise Panel

A Product Market Theory of Training and Turnover in 5 Firms

Why Funding is not a Solution to the "Social 3 Security Crisis"
07/01

07/01

07/01

07/01

07/01 
